\title{
INVESTIGATING IRAN'S TRADITIONAL DISPLAY APPROACH IN DISPLAY MUSEUM DESIGN: A CASE STUDY IN KISH ISLAND
}

\author{
Samaneh Takhtkeshian \\ MS.c in Architecture, Kish International Branch, Islamic Azad University, Kish, Iran
}

Mohammad Mehdi Ghiai

Assistant Professor, Department of Architecture and Urbanism, Shahid Rajaee Teacher Training, University, Tehran, Iran

\begin{abstract}
Museum reflects thoughts and creativities of human that expresses his content with specific language namely, the real language of thing. Therefore, building a museum should be on the basis of cultural statute and certain regulations such as cultural requirement, religious, historical, tourism value, geographical area, proximity to centers of science and culture are the criteria for its building. Also, human consigns his past and present to the museum to regularly refer to it and to think about his future. Display due to its long history can represent the history of Iranian culture during different periods because display in different periods has been influenced by religion, policy and so on and history of display can be considered as cultural representation and factor. Due to the volume of visitors in Kish Island and paying special attention to business centers and hotel lead to the lack of attention to cultural centers and due to the touristic potential of Kish Island, this potential can be used to expose the museum to everyone. This study investigates Iran's traditional display approach in display museum design in Kish Island through descriptive - analytical research method to provide an area to promote human intellectual structure in the art as well as a suitable context for innovative artistic technology and creativities.
\end{abstract}

Keywords: museum, traditional display, Iran, Kish Island

\section{INTRODUCTION}

Display at the beginning was emerged of the transformation of traditions and religious prayers and its foundation has been commons. Display has strong background in Iran and is very rich. Display literally means the rhetoric, image and movement. "In the beginning, display is summarized in one or two actors that tell audience story and gradually became a two-person conversation and then rose to more people" (Champion, 1983, 152). Initially, scene displays is regarded as a part of religious ceremonies. Display is present in the structure of society as an effective and dynamic art. Display is a mysterious and social art and its consideration leads to cultural boom. It seems that using traditional display can help to enrich the display museum, because the traditional display has wide field and can also reflect the unknown values. Also, by use this approach the display art of Iran can become the display arena for the public. To check the winding path that the display art has passed in Iran initially, it is essential to define two words of "display" and "theater" to make clear the reason of choosing the title of this investigation. "Display" in a simple definition refers to all of the movements and actions that are taken to indicate a subject. Therefore, display at its core and in its original form is a game and the game is obviously an instinctive phenomenon. Play is one of man's natural instincts and in this regard often something is displayed that has already happened. In other words, display means showing, opening and is synonymous to terms like watch, imitation and play. Thus, each of the various forms and branches of this art is a part of the concept of display. "Theatre" is the dramatic art that five centuries before Christ was born in Athens and Rome and then continued in the works of Medieval, Renaissance and later in the new era of Europe. The purpose of the theater is an art collection or an organized system of art that first of all need text or drama and then the director which include acting, choreography, sculptural decoration, music, oratory, lighting, painting, architecture and so on. Drama is emerged among nations even before the architecture and then these artists by the help of architecture have established the place of display and required spaces for more appropriate induction of concepts and expression. Also, due to the absence of such special center in Iran and the need of artists and art lovers to such a center it was decided to design this space. The purpose of this design is also to show the old and new world of Iranian display with geometry and architecture. The purpose of defining and explaining the display 
museum of the evidences and works left by the last man and his environment is collecting and preserving and spiritual exploiting of works and creating relation between them particularly showing works. Display museum has a role in education and an impact in obtaining credit and international identity for country. Display museum accommodates identity of country in itself, the museum also familiarize today's generation with the evolution process of display art in detail and through a new style of architecture on the principles, methods and traditions can create strong relationship between architecture and traditional display and can provide the access to artists. Also, the archive of display is found completely and people can visit the museum to improve their knowledge and culture. In such a dynamic context, we can see the formation of new ideas and thoughts that underpin the growing and productive movement for a better tomorrow. Now, the performance of an architect as the creator of display space is important in such an environment that in every second mind is engaged and responsive to many issues.

\section{MUSEUM}

The museum reflects human thoughts and creativities that express his content with specific language namely, the real language of thing. Museum is mental life towards the past and creating a museum should be based on cultural statute and certain regulations such as cultural need, religious, historical, tourism value, geographical area, proximity to scientific centers are the criteria for its building. Also, human consigns his past and present to the museum to regularly refer to it and to think about his future. The preservation of display values in the form of museum have been neglected in Iran. Unfortunately, social and political conditions never are not consistent so much with Iranian traditional theater art so that such art to able to survive long periods of time. This period is necessary for its evolution and converting it into an independent and complete art (Tavosi, 2002). For example, in the territory of our neighbor, there are museums with Iranian puppet dolls from the Seljuk era until today, but here there is no sign of them in museums (Beyzaei, 2008). In Iran, attention is paid to art museums such as sculpture, painting, photos, etc. but in the branches of dramatic, a special space is not dedicated to the display so far. Museums instead of being a places for permanent collections, are converted to temporary exhibitions. From the traditional perspective, an artwork is something that embodies everything and gives it an immediate visibility.

Table 1. (Source: Adapted from the book of Display in Iran from Beyzaei)

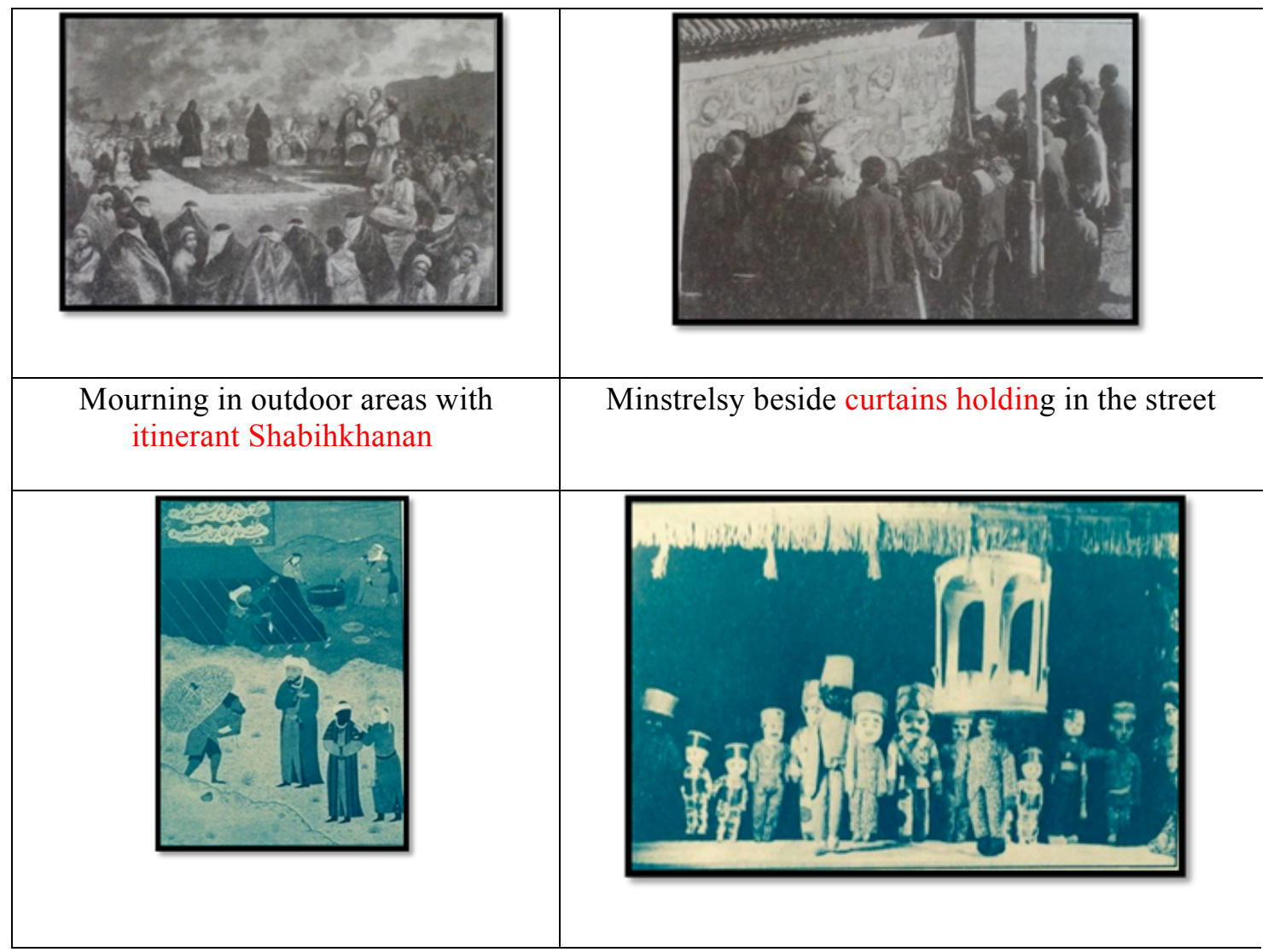


\begin{tabular}{|l|l|}
\hline Painting ((Black)) exhilarating drama & Various figures of Iranian dolls \\
\hline
\end{tabular}

Table 2. Definition of museum (Source: author)

\begin{tabular}{|c|c|}
\hline Montazeri, 1990 & $\begin{array}{r}\text { Promoting the use of museums, the launch of new museums and preventing looting } \\
\text { antiquities and artefacts, etc. are some of the important actions. }\end{array}$ \\
\hline Cloud, 1985 & $\begin{array}{r}\text { The museum is the only institution that speaks the language of real things. } \\
\text { Museum is a center for training all people through their participation in creativity } \\
\text { and cultural continuity. }\end{array}$ \\
\hline $\begin{array}{c}\text { Statute of the International } \\
\text { Council of Museums } \\
\text { ICOM, 1976 }\end{array}$ & $\begin{array}{r}\text { The museum is a permanent institution with no material target that its doors are } \\
\text { open for public and serve to the community and for its development. }\end{array}$ \\
\hline
\end{tabular}

\section{THE HISTORY OF MUSEUM IN IRAN}

Museum with its modern concept was formed in Iran 120 years ago. The first example can be seen in the reign of Mohammad Ali Shah. At the time of the Shah Qajar a season of Golestan Palace became the Museum of valuable and royal objects that were visited by lords and nobles. In 1295 Hijri Shamsi, when Murtaza Khan Momtazoalmolk was in charge of the Ministry of Education and Endowments, a small office as antiquities branch was established at this ministry and later this branch was renamed to antiquities circle which continued its activities under the auspices of the General Directorate of Education. Actually, Murtaza Khan Momtazoalmolk has been the founder of the first National Museum of Iran and tried so much to form a rich and valuable museum in Tehran. He could establish the National Museum of Iran with 270 antique objects in one of the big rooms of old mansion of the Ministry of Education that was in the northern part of the Darolfonoon School and after purchasing and donating the Masoudieh Palace (the current site of the Ministry of Education located on the Ekbatan street), the museum was moved to the Hall of Mirrors of that Palace (1304 Hijri Shamsi). To develop and promote traditional arts the National Art Museum was built next to spring house of Negarestan garden by command of Reza Khan and next to the museum local workshops were considered to produce and present the works. In 1310 Hijri Shamsi with the discovery of ancient relics in Persepolis the Persepolis Museum was established to preserve these objects. In 1314 Hijri Shamsi the building of the Museum of Anthropology of Iran was founded and after 20 years Museum of Anthropology was opened in Armenian Street (Bu Ali) to provide better works, the Anthropology museum was moved to Abyaz Palace next to the Golestan palace, the oldest museum of country (1968 Hijri Shamsi). In 1962 the Museum of Tabriz and Gorgan, in 1966 the Susa Museum and in 1967 the Urmia museum was opened and the works in the museum have historical and anthropology aspects. Rasht Museum in 1970 and the museum of bathroom of Ganjalikhan Kerman was established in 1971. Museum of Cultural Complex of Freedom in 1970 and the museum of Saba house in the residential home of deceased Saba in 1973 was founded and opened. From 1980 onwards wider changes were done in the development and completion and equipping of Iran's museums. For example, we can point to the decorative arts museums of anthropology, Saba in Tehran, Rasht, Abadan, Susa, Seven Hills, Qazvin, Roudesar palace, Shahpur fort in Khorramabad and finally, the Pars Museum in Arg Karimkhani of Shiraz. The year 1976 was the height of museum building in Iran. In this year the motivation to establish the buildings only for museum become common and Contemporary Art Museum, rugs, Culture House of Niyavaran are its results.

Table 3. Types of the museum (Source: author)

\begin{tabular}{|l|l}
\hline Historical Museums & $\begin{array}{l}\text { All museums whose collections were formed and released from historical } \\
\text { perspective are considered as historical museum which aim to present } \\
\text { chronological documentation to a string of events or a complex that } \\
\text { represents a moment of the change moment. }\end{array}$ \\
\hline
\end{tabular}




\begin{tabular}{|l|l}
\hline Scientific museums & $\begin{array}{l}\text { Natural science museums, museums of applied science and technical } \\
\text { museums (with the exception of science and technology museums, which are } \\
\text { considered historical) are regarded as scientific museums. }\end{array}$ \\
\hline Specialized museums & $\begin{array}{l}\text { Many of these museums are indicative of limited economic activities (such } \\
\text { as mineral exploration, shoe industry) and in such cases, more or less we } \\
\text { dependent on the industries in which we are illustrated in them. }\end{array}$ \\
\hline Regional museums & $\begin{array}{l}\text { Regional or local Museums which introduce all aspects of (natural, historical } \\
\text { and artistic) a state or province. }\end{array}$ \\
\hline Museums of free space & $\begin{array}{l}\text { Museums that have a specific building for display and have been deployed } \\
\text { within the confines of a garden or a park and their objects are offered in the } \\
\text { open air. }\end{array}$ \\
\hline $\begin{array}{l}\text { Buildings converted to a } \\
\text { museum }\end{array}$ & $\begin{array}{l}\text { Most museums that were created between } 1800 \text { and } 1950 \text { were housed in } \\
\text { existing historic buildings. }\end{array}$ \\
\hline
\end{tabular}

\section{THE ROLE OF MUSEUM IN REVIVING THE ART}

If artistic creativity to be considered as a natural human need, the role of museum as a place of gathering and delivering of these innovations becomes clearer. In present arena museums go beyond the mere collection of artworks, identification, maintenance and supply works in the desirable form. Museums have accepted the responsibility to taught the truth to all much more than what they know and also have accepted to offer new opinions and ideas to those who individually or collectively, accidental or purposeful come to visit. One of the today's living needs is cultural monuments of a society. Communities advance more quickly and efforts to consolidate cultural foundations of society and this issue requires the promotion of intellectual structures of individuals of society. Economic and social changes constantly associated with changes in the way of thinking and behavior of people of a community. Cultural system has been on the basis of a particular form of production and a collection of customs and at the same time a new development requires new targets. If in the early stages of social evolution of Iran needs had economic stimulus, at this stage of reflection the spiritual and cultural demands and aspirations of individuals were obvious. Considering these needs in Iran in relation to cultural heritage and constant contact with the West civilization is crucial because a group of people has ignored the cultural background of this country and is fascinated by the lifestyle of West and others have known the entrance of some manifestations of the industrial civilization as a sign of the lack of interest and maintaining Iranian tradition. Due to the economic and social developments of Iran, society now needs a culture which to be based on the principles of true culture and can be effective on Iranians' life especially young people in an industrial society. The main purpose is to create the favorable human personality that should train an individual in the physical and social and spiritual areas and also need a culture that is based on a national culture namely, the revival of genuine values of Iranian culture and its adaption to modern living conditions and also enjoying the manifestations of global culture. According to what was mentioned previously, the need for a general purpose and ideology for young people that can attract them totally is the physical, social, spiritual purpose respectively which requires a cultural policy.

Table 4. Iranian traditional display (Source: author)

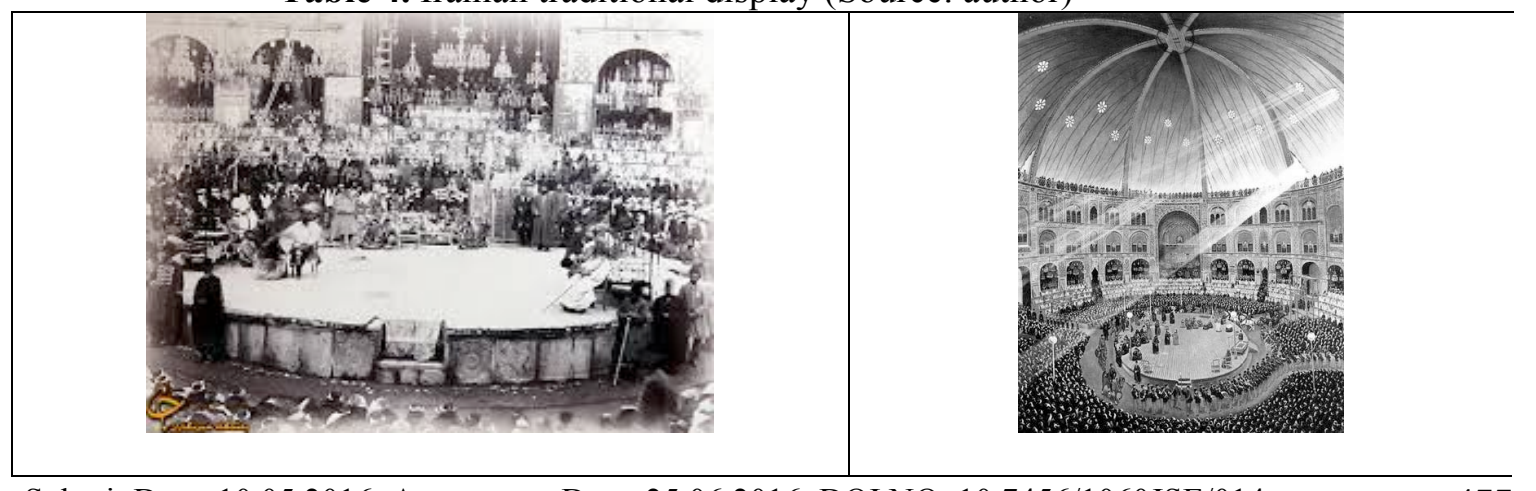

Submit Date: 10.05.2016, Acceptance Date: 25.06.2016, DOI NO: 10.7456/1060JSE/014

Copyright (C) The Turkish Online Journal of Design, Art and Communication 


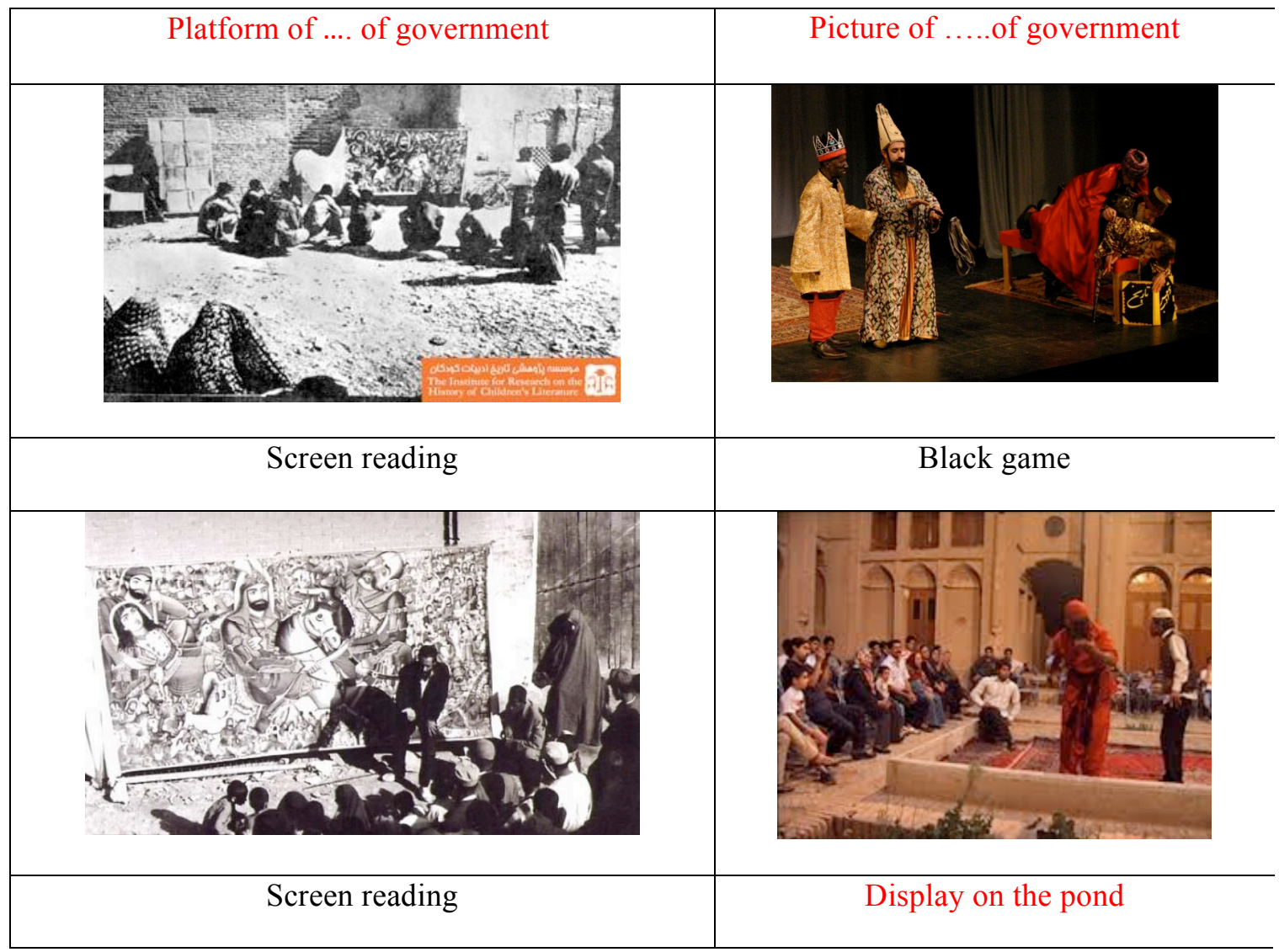

Table 5. Performing Art (Source: Dadvar, 2013 and Ganji, Mohtadi, 2012 and Varjavand, 2014, and Akrami, 2014)

\begin{tabular}{|l|l}
\hline Performing Arts & $\begin{array}{l}\text { Display every day can show a period of present, past and even the future by } \\
\text { the language and theater. This live feature of theater is a reason for its live } \\
\text { performing. }\end{array}$ \\
\hline $\begin{array}{l}\text { Museum and } \\
\text { display }\end{array}$ & $\begin{array}{l}\text { Display museum has a role in education and influences obtaining credit and } \\
\text { international identity of country. Display museum contains the national } \\
\text { identity. This museum familiarize today's generation with the evolution of } \\
\text { display art in detail. }\end{array}$ \\
\hline $\begin{array}{l}\text { Traditional } \\
\text { display }\end{array}$ & $\begin{array}{l}\text { In this type of display people were not only audience but they were regarded } \\
\text { as residents of the same streets and cities that participated in some way in } \\
\text { making this art. Art is not just for everyone but it was by everyone. }\end{array}$ \\
\hline $\begin{array}{l}\text { Traditional } \\
\text { rituals, ritual } \\
\text { traditions }\end{array}$ & $\begin{array}{l}\text { Although tradition in word means conduct and manner, but in conceptual } \\
\text { term refers to ceremonies, rituals and behaviors that according to the belief } \\
\text { of some people it has a divine origin that through different well-known } \\
\text { characters such as the Apostles and Prophet has been revealed to mankind in } \\
\text { different periods. }\end{array}$ \\
\hline
\end{tabular}

\section{KISH ISLAND}

Kish Island with an area of 91 square kilometers, about 43 kilometers beach with oval shape is located in 18 kilometers distance from Levantine port (Sun Port) - Iran's continued land - in Persian Gulf. Kish is located in the first quarter along the coast of 1359 kilometers of north of Iran in the mouth of the Persian Gulf and almost near the end of this waterway in the range of Strait of Hormuz. The maximum width of the island along the southern coast to the northern coast (the distance of Customs Harbour- Lighthouse) is $7.5 \mathrm{~km}$. The

Submit Date: 10.05.2016, Acceptance Date: 25.06.2016, DOI NO: 10.7456/1060JSE/014 
island lacks special topography like mountains and even high hills. Kish International Airport is constructed in the center and in its highlands that has about 40-35 meters height. The maximum slope of the island is from the north of the airport towards the coast (Shayan Hotel). Due to the lack of a cultural, artistic place, museum, cinema and theater and etc. it is decided to design this center in Kish Island in order to pay attention to the cultural structure of Kish. It seems that in Kish Island due to the volume of visitors and paying special attention to business centers and hotel lead to the lack of attention to cultural centers and due to the touristic nature of Kish Island, this potential can be used to expose the museum to everyone. The form in this design is also considered more due to the hot and humid climate and includes the limitations such as how to get on the site, severe sunlight on the island that influences the openings, the type of form, materials, height and so on.

Table 6. Investigating the characteristics of the Kish Island (Source: author)

\begin{tabular}{|l|l}
\hline Cultural Studies & $\begin{array}{l}\text { The population growth and prediction of converting Kish into a great } \\
\text { international tourist center and the need to introduce Iranian and Islamic } \\
\text { culture lead the Kish Free Zone Organization pays particular attention to } \\
\text { the development of cultural facilities. }\end{array}$ \\
\hline $\begin{array}{l}\text { Kish historical relics } \\
\text { and monuments }\end{array}$ & $\begin{array}{l}\text { One of the main monuments of the island is the remains of the historic } \\
\text { city of porridge which is located in the north of the Kish island. House } \\
\text { of Lords, bathrooms, set of Harbour City, ancient aqueducts and ancient } \\
\text { mosque are ancient works that have already been identified and } \\
\text { unearthed in this historical city. }\end{array}$ \\
\hline $\begin{array}{l}\text { Characteristics of } \\
\text { local places of Kish }\end{array}$ & $\begin{array}{l}\text { The existence of multiple squares at the district level in addition to } \\
\text { creating openness in places and helping the blind air, has important } \\
\text { social roles. Children play in these squares. The shadow of existing trees } \\
\text { around the square is a hangout for young people in different age groups. }\end{array}$ \\
\hline $\begin{array}{l}\text { Kish tourism } \\
\text { attraction }\end{array}$ & $\begin{array}{l}\text { For years, Kish island is known as a major destination of Iranian and } \\
\text { foreign tourists and existence of tens of natural, historical and cultural } \\
\text { attractions in it, has made the memorable trip for tourists. }\end{array}$ \\
\hline
\end{tabular}

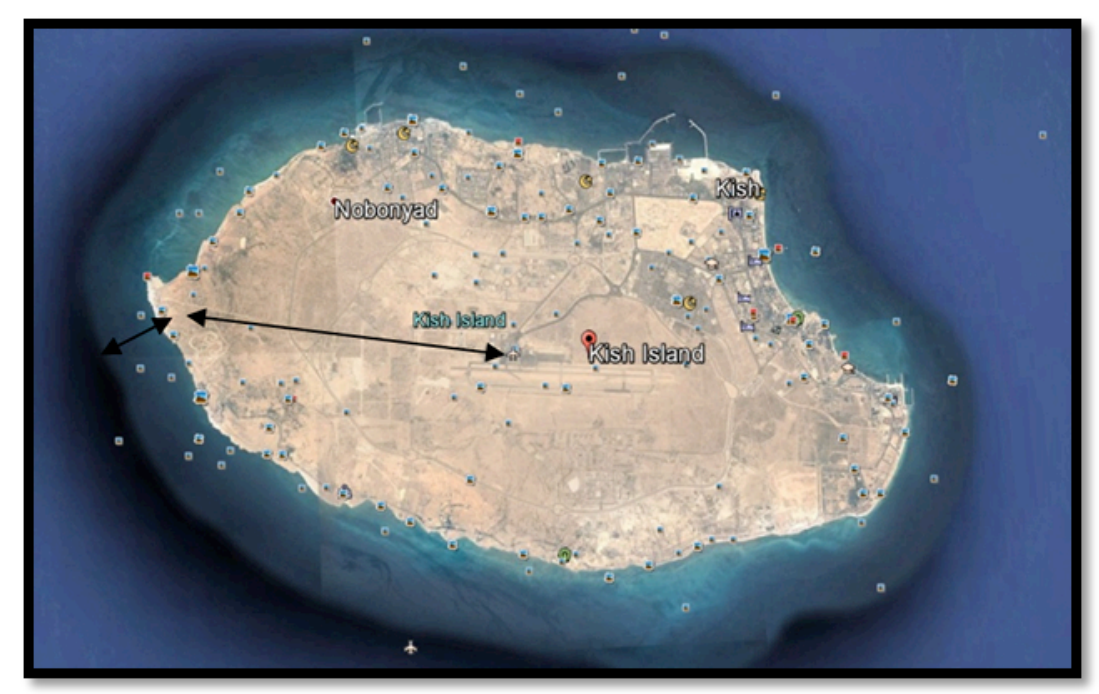

Figure 1. Aerial photo of the Kish Island (Google earth)

\section{APPROACH TO REVIVE THE TRADITIONAL DISPLAY}


Iranian traditional displays in the field of view of elders and artists, especially writers were not considered as an art or a means for serious expression and had not had cultural recognition never and almost always have been in the hands of commons. Perhaps people have felt its necessity much more that sometimes had considered it seriously. But because upper event writers were inattentive towards whatever related to common people thus, nobody has recorded their displays and this trend continued in the different era until the rise of Islam. After Islam display has been as art in different forms ranging from mourning, storytellers, joyful drama, and showing puppet. In an era in which arenas of communications, geography and policy have long lost their traditional boundaries, performing arts that are perhaps the oldest sibling of human beings not to be adhere to the boundaries of race, nationality and monoculturalism so much. For this reason, nightlife of the linchpin again seems necessary to return to our originality. In this regard, according to Mirfakhraei, our traditional companionship accompanies by an intimacy that does not exist in today's modern (Mirfakhraei, 1998, 12). For this reason, the combination of contemporary art with the traditional approach is important matter because display is a historical step that by passing its evolution process will lead to the theater. Reviving the traditional display is the purpose of this approach beside the current displays and each in its place and in the form of a museum. According to the conducted studies, scenes of traditional display are completely different from the atmosphere of the scene of today's displays, but over time, all have been terminated to the theater venues. One of the major differences is in the scene. We do not perform in round scene but in the one-way and three-way scenes and the other issue is lighting. There is no natural light thus, the issue of selecting color is also proposed (Pesyani, 1998, 14).

Table 7. Ideas for the revival of traditional display (source: author)

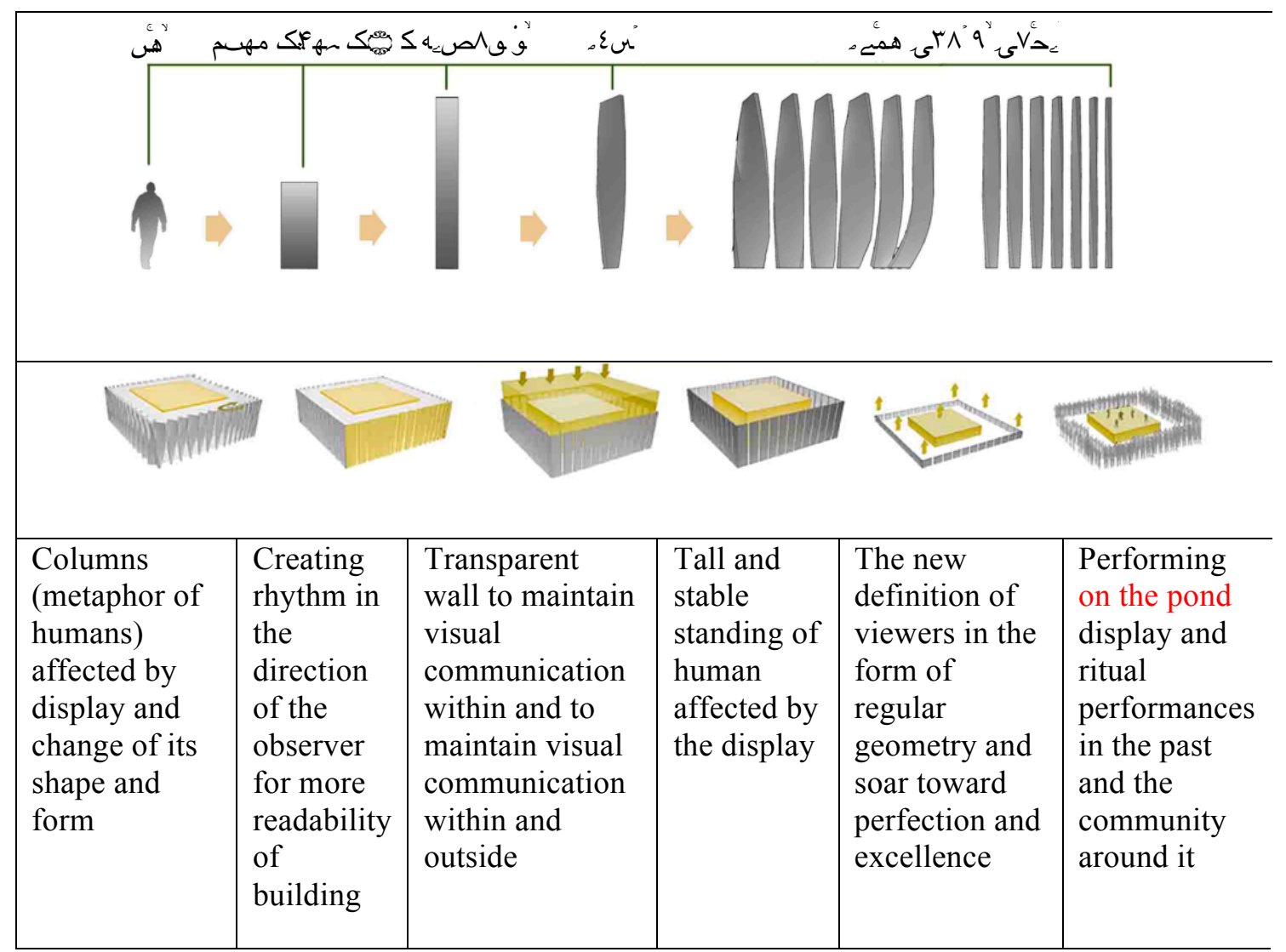

This approach tries to show the position of traditional display to reflect its originality as far as possible. In this regard Mirfakhraei says: I am opposed to the mourning or on the pond in the framework of European theater namely the European theater to be performed in the architecture because the connection of the audience with actors in this kind of spaces would not be as it is in traditional displays. Mourning display should be performed in its line namely making it modern does not mean performing it in European style and it should be in the form of mourning then new events to be created based on it. These actions should be done freely to do not damage the context of theater (Mirfakhraei, 1998, 12) because our displays are tradition with 
the concept of people (Pesyani, 1998, 13). Considering reviving traditional displays, scenes of theater halls should be destroyed to make more relationship between spectator and the scene (Mirfakhraei, 1998, 12). Today's scenes of theatre is completely different from traditional displays' scenes consequently, performing traditional displays in these scenes is not meaningful. "I think designing the scene of such displays basically requires non-performing status where people can gather there like squares or grasslands that gradually become roofed places to protect spectators and actors from the rain and sun. In my opinion the suitable place for performing it is the place that is performed previously in it but today's theater adapted from them is different (Pesyani, 1998, 14). Today, mourning displays which were performed in squares due to the status quo of society cannot be performed there now and because a special place is not provided to these spaces thus, these type of displays are forgotten and a place should be designed according to the needs of these type of displays.

Ideas for design based on idea showing and idea Iranian belief

Iranian theater is the purpose of uniting people who have wandered away

Square the circle symbolizes the sky: a shell that sits on the ground

Creating open spaces for street performances and traditional
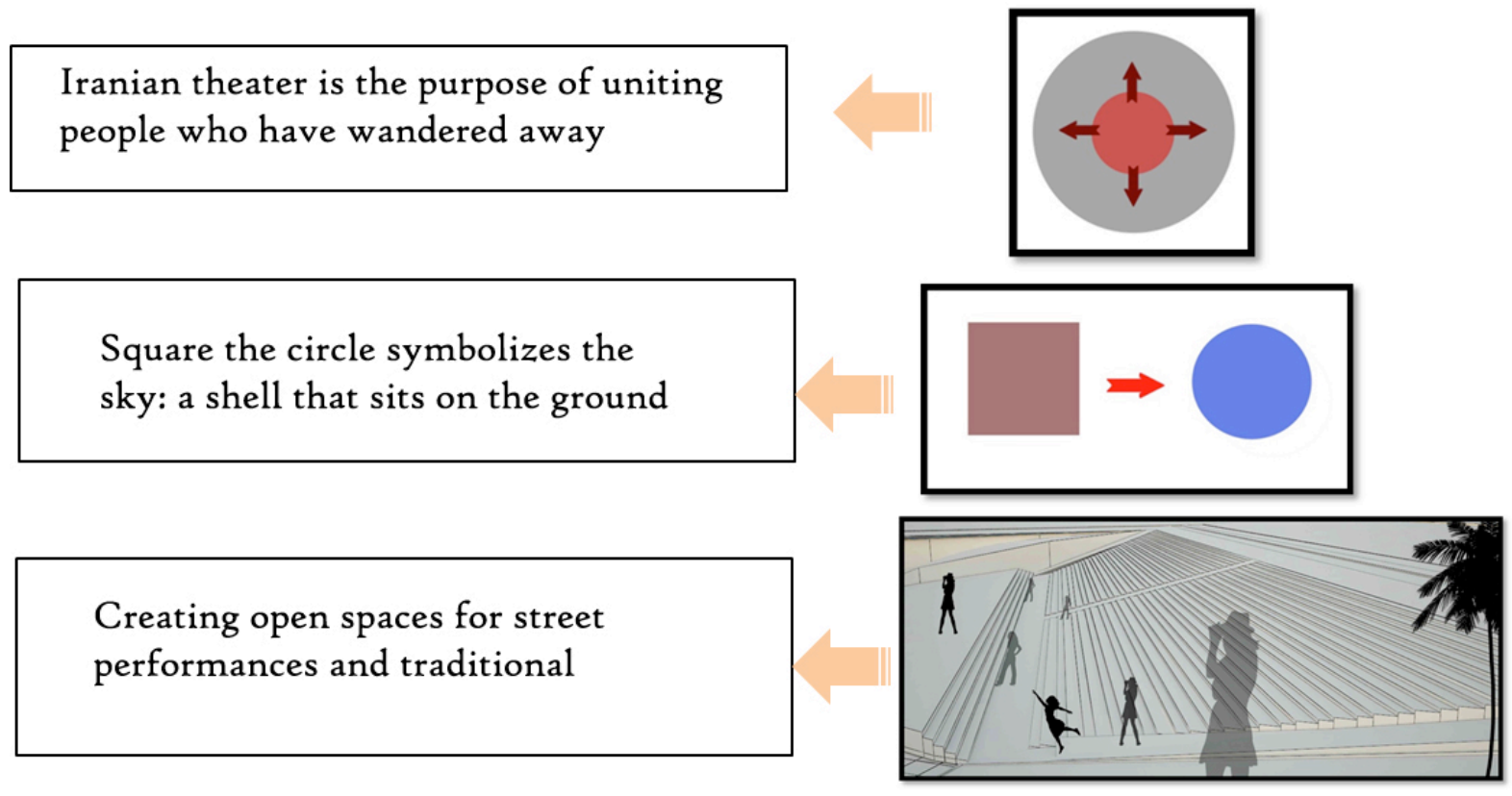

Create scenes without the behind the scenes and sense of space

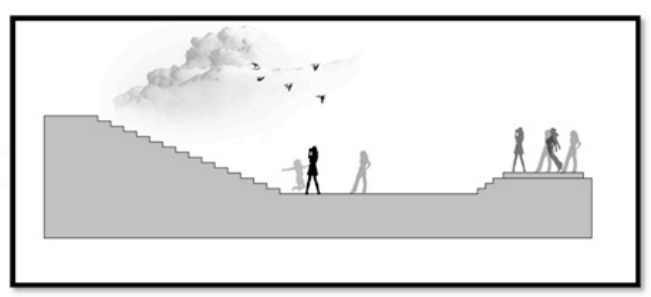

Figure 2. Design Ideas (Source: author) 


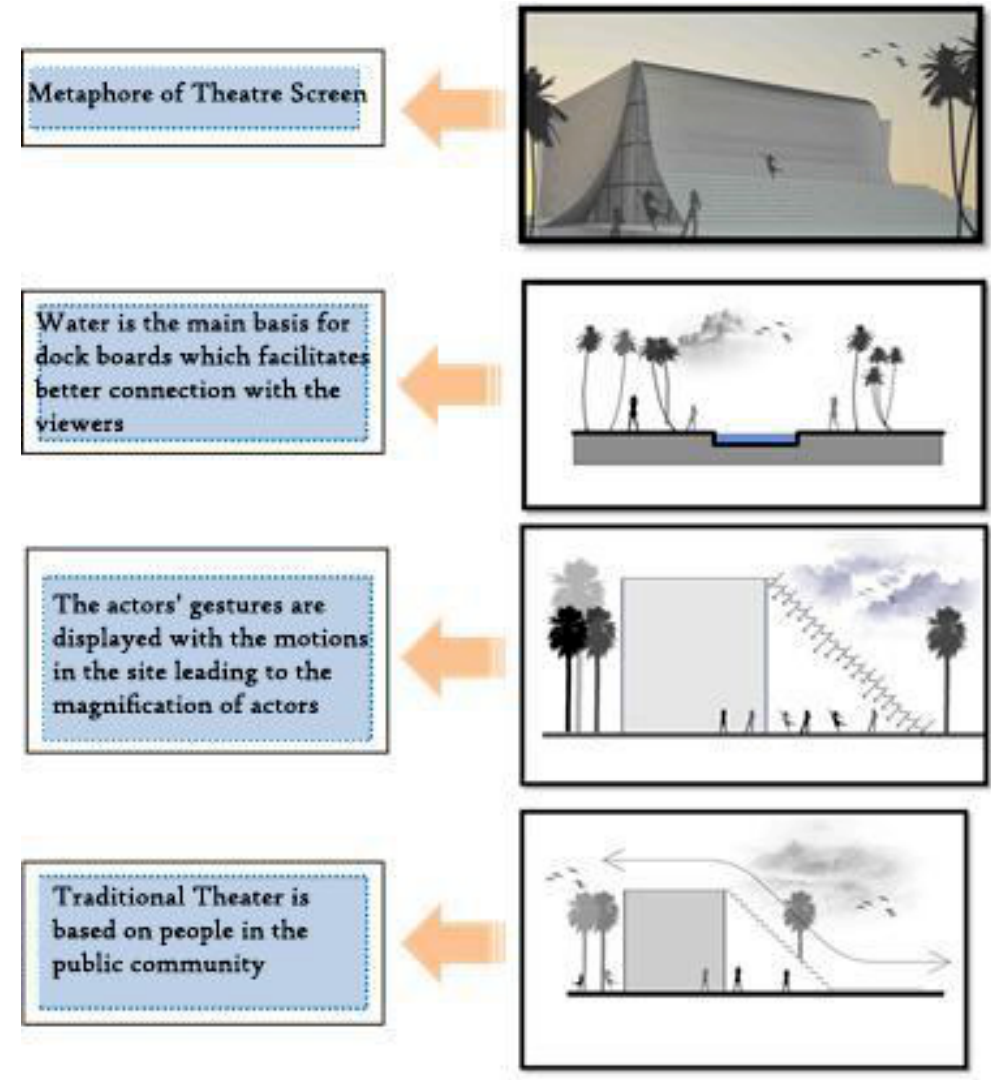

Figure 3. Ideas to revive the traditional display (Source: author)

\section{CONCLUSION}

Iranian traditional displays in the field of view of elders and artists, especially writers were not regarded as an art or a means for serious expression and had not had cultural recognition never and almost always have been in the hands of commons. Perhaps people have felt its necessity much more that sometimes had paid attention to it seriously. But because lord event writers were inattentive towards whatever related to common people thus, nobody has recorded their displays and this trend continued in the different era until the rise of Islam. After Islam display has been as art in different forms ranging from mourning, storytellers, joyful drama, and showing puppet. In an era in which arenas of communications, geography and policy have long lost their traditional boundaries, performing arts that are perhaps the oldest sibling of human beings not to be adhere to the boundaries of race, nationality and monoculturalism so much. Therefore, nightlife of the linchpin again seems necessary to return to our originality. In this regard, according to Mirfakhraei, our traditional companionship accompanies by an intimacy that does not exist in today's modern world. For this reason, the combination of contemporary art with the traditional approach is important matter because display is a historical step that by passing its evolution process will lead to the theater.

Reviving the traditional display is the purpose of this approach beside the current displays and each in its place and in the form of a museum. Traditional display scenes are completely different from the atmosphere of the scene of today's displays, but over time, all have been terminated to the theater venues. One of the major differences is in the scene. We do not perform in round scene but in the one-way and three-way scenes and the other issue is lighting. There is no natural light thus, the issue of selecting color is also proposed. This approach tries to show the position of traditional display to reflect its originality as far as possible. In this regard Mirfakhraei says: I am opposed to the mourning or on the pond in the framework of European theater namely the European theater to be performed in the architecture because the connection of the audience with actors in this kind of spaces would not be as it is in traditional displays.

\section{REFERENCES}


Asharfi, M. (2000). A comparative concept of echo-museum and traditional museums. Letter of architecture to urban planning, 2(4), 61-75.

Beizaei, B. (2008). Show in Iran, Volume 1, Tehran: Intellectuals and Women's Studies Publication.

Dadvar, N. (2013). Theatre Alphabet . Tehran: Afraz publication, $2^{\text {nd }}$ edition.

Dieulafoy, J. (1997). Itinerary: Memories of Susa excavated from 1884-1886 (Trans: I. Gharevashi). Tehran: Tehran University Publication.

Ernest, N. (1984). Architecture Data (Trans: H. Motabi). Tehran: Zadeh publication.

Fakhar, Z., \& Haeri, N. (1987). Assessing the suitability of museum architecture with the existing cultural property in order to improve the performance of museum. Payme bastanshenas Journal, 5 (9), 61-76.

Fakhraei, M., Pesyani, A., \& Rahmanian, M. (1998). Theatre Quarterly Journal, 1 (4), 12-18.

Ghahramani, S. (1983). The first book of Cinema, Volume 1, Tehran: Iran Mostanad Publication.

Jihani Mansori, E. (2012). Recovery of spatial structure and shape of the Ferdous garden in Shamiran. Cultural and Historical Texture Reconstructions Journal, 2 (3).

Kalvi, A. (2009). Refreshing cultural-historical context of Ferdous Garden. Landscape Architecture Internet Journal, 42.

Khaki, M.R. (2000). Change in theatre places in the $20^{\text {th }}$ century. Art and Architecture Journal, 44, 37-44.

Khanizad, Sh. (2012). Designing Museum in Iran and around the world. Tehran: Century Art and Architecture Publication.

Moayeri, M.A. (1973). Ferdous Garden. Yaghma Magazine, 303, 529-532.

Mohtamedi, M. (2002). Historical Geography of Tehran. Tehran: Tehran University Publication Center.

Nemat Tavosi, M. (2002). Iran traditional theatre. Mahe Honar Magazine, 45 \& 46, 40-45.

Research and Technology Deputy of University Jihad (2007). Reviewing and providing standards for the protection of works in the museums of Tehran, Tehran. 